Jurnal Ilmu dan Teknologi Kesehatan

Vol 9, No 1, Sept 2021

ISSN: 2338-9095 (Print)

ISSN: 2338-9109 (online)

\title{
Physical Exercise Reduce Fatigue in Children With Leukemia
}

\author{
Apriyanti $^{1}$, Mayetti ${ }^{2}$, Deswita $^{1^{*}}$ \\ ${ }^{1}$ Nursing Faculty Universitas Andalas Padang, Indonesia \\ ${ }^{2}$ Pediatric Departement RSUP Dr. M. Djamil Padang, Indonesia \\ *Email:deswita@nrs.unand.ac.id
}

\section{Article history \\ Posted, Jul $21^{\text {th }}, 2021$ \\ Reviewed, Aug $23^{\text {th }}, 2021$ \\ Received, Sep $4^{\text {th }}, 2021$}

\begin{abstract}
Fatigue is a complaint that many children with Acute lymphoblastic leukemia (ALL) feel while undergoing chemotherapy and is a multidimensional problem. The condition of fatigue that children continuously feel requires treatment from health workers. To optimize physical exercise interventions, researchers combined physical exercise with Levine theory based on four conservation principles to increase patient activity during treatment. The goal of the study was to provide physical exercise to children with ALL undergoing chemotherapy. The research method is quantitative with Quasy Experimen With Control Group Pre-Test-Post-Test Design. This study sample of ALL children aged 8-13 years who underwent maintenance phase chemotherapy. The sample was taken using consecutive sampling techniques with a total of 22 people. The data collection tool uses the Multidimensional Fatigue Scale questionnaire. The results showed that the average fatigue scale in the pre-test intervention group was 31.18 and post-test 47.64. The pre-test control group was 27.27 and post-test 39.18. The level of fatigue experienced by children decreased ( $p 0.000$ ) after being given physical exercise walking 5 minutes, six times in 14 days. The involvement of health workers is expected in conducting a comprehensive assessment of fatigue symptoms, and the results of this study can be used as one of the physical exercise interventions in the management of fatigue in children with leukemia.
\end{abstract}

Keywords: chemotherapy; childhood; fatigue; leukemia; physical exercise

\begin{abstract}
ABSTRAK
Kelelahan merupakan keluhan yang banyak dirasakan anak dengan Leukemia Limfoblastik Akut (LLA) pada saat menjalani kemoterapi dan merupakan masalah multidimentional. Kondisi kelelahan yang terus menerus dirasakan anak membutuhkan penanganan dari tenaga kesehatan. Untuk mengoptimalkan intervensi latihan fisik peneliti mengkombinasikan latihan fisik dengan teori Levine berdasarkan 4 prinsip konservasi sehingga untuk meningkatkan aktivitas pasien selama pengobatan. Tujuan penelitian ini adalah untuk memberikan latihan fisik pada anak dengan LLA yang menjalani kemoterapi. Metode penelitian yaitu kuantitatif dengan Quasy Experiment With Control Group Pre-Test-Post-Test Design. Sampel penelitian ini anak LLA usia 8-13 tahun yang menjalani kemoterapi fase maintanance. Sampel diambil menggunakan teknik consecutive sampling dengan jumlah 22 orang. Alat pengumpulan data menggunakan kuesioner Multidimentional Fatigue Scale. Hasil penelitian memperlihatkan
\end{abstract}


bahwa rata-rata skala kelelahan pada kelompok intervensi pre test adalah 31,18 dan post test 47,64. Pada kelompok kontrol pre test adalah 27,27 dan post test 39,18 . Tingkat kelelahan yang dialami anak mengalami penurunan $(p=0.000)$ setelah diberikan latihan fisik berjalan kaki 5 menit, selama 6 kali dalam 14 hari. Adanya keterlibatan tenaga kesehatan sangat diharapkan dalam melakukan pengkajian yang komprehensif terhadap gejala kelelahan dan hasil penelitian ini dapat dijadikan sebagai salah satu intervensi latihan fisik dalam pengelolaan kelelahan pada anak dengan leukemia.

Kata Kunci: kemoterapi; anak; kelelahan; leukemia; latihan fisik

\section{INTRODUCTION}

Acute lymphoblastic leukemia (ALL) is a malignancy that often occurs in children. This condition is widely found in children under 15 years and is more common at 3-4 years (Apriany, 2016). According to the Union for International Center Control Database, children suffering from ALL are mostly from low- and middle-income countries (Mendri and Prayogi, 2016). According to the Global Cancer Statistics, there was an increase in ALL from all countries, as many as $2.4 \%$ of new cases and $3.2 \%$ of deaths in 2018 (World Health Organization, 2018). ALL incidents occur around $2.5-4.0$ per 100,000 children, with an estimated 2.000-3.200 new cases each year (Kemenkes RI, 2019). While based on the Medical Record Database at RSUP DR.M. Djamil Padang, all child incidents are found as many as 26-30 new cases every year, where boys (60\%) and girls (40\%) (Rekam Medis RSUP dr. M.Djamil, 2020).

It is still not known exactly the risk factors and causes of ALL in children. This is thought to be the interaction of four factors: genetic factors, chemicals, viruses, and radiation. Therefore, the pathological state and the facilitation of several causative factors can increase the risk of all development, the need for treatment evaluation and monitoring by pediatric oncologists (Jitowiyono, 2018). According to Apriany (2016), there are several ways of medical management for the treatment of ALL, one of which is the act of chemotherapy. Chemotherapy itself becomes the primary treatment for children with ALL. According to Mendri and Prayogi (2016), chemotherapy is one of the treatments to inhibit the growth of cancer cells. However, the act of chemotherapy has several side effects, some of which are fatigue or fatigue. Fatigue or fatigue, commonly called cancer-related fatigue, is a subjective condition in the form of a feeling of continuous fatigue associated with fatigue.

According to Goric (2008), regular and controlled physical exercise can positively impact if done within five days during the week. Physical exercise interventions are 
easy to do in daily activities, beneficial and can affect the health of cancer patients after diagnosis. Based on the latest data from several research results, physical exercise can prevent cancer death, lower fatigue scores, improve feelings of happiness, and improve quality of life in cancer patients (NCCN, 2017). Physical exercise in all children increases cardiorespiratory, increases muscle endurance, increases the oxidation of carbohydrates and fats, increases myoglobin content, and decreases muscle loss. It is the challenge of researchers choosing physical exercise interventions in the management of fatigue and being able to be done in all children in the maintenance phase with a uniform treatment protocol, then existing research is still limited. The purpose of this research was to provide physical exercise to children with ALL undergoing chemotherapy.

\section{METHOD}

The research design used quantitative research with a quasi-experiment approach with a control group pre-test-post-test design. The population in this study was all children aged 8-13 years, outpatients who will do chemotherapy at RSUP Dr.M. Djamil Padang. The sample size in this study is 22 children, and the sampling technique with consecutive sampling. The inclusion criteria are; children diagnosed with ALL ages 8-13 years, who are in remission and undergoing chemotherapy in the maintenance chemotherapy phase, all child patients who undergo chemotherapy, can communicate and can do daily physical activity, who have no problems in the laboratory values: $\mathrm{Hb}>10 \mathrm{~g} / \mathrm{dl}$, Leukocytes $>2,000 \mathrm{~mm}^{3}$; Thrombocyte $>50,000 \mathrm{~mm}^{3}$ (from the results of laboratory examinations, at least two days after being taken and qualified chemotherapy), does not experience vision, hearing or perception problems, does not have dysfunction, parents agree, and children are willing to participate in this study.

Before the study was conducted, researchers first conducted an ethical review at RSUP Dr. M. Djamil and have passed the ethics review on April $5^{\text {th }} 2021$, with the number: 100 / KEKP / 2021. Then after being declared graduated, researchers are permitted to conduct research. This study was conducted from April to July 2021. This study was conducted in the outpatient room of Dr.M. Djamil Padang Hospital sick children, a patient halfway house of the patient's home and lodging. Then the researchers coordinated with the head of the outpatient installation, the head of the hospital clinic room and parties related to the study (the manager of the patient halfway house). 
Furthermore, researchers selected the study subjects by the criteria of inclusion. Subjects with odd sequence numbers made intervention groups and even sequence numbers made into control groups. The odd sequence number will be changed with code A (Intervention) and even sequence number with code B (Control), consisting of 11 children. In this study, given physical exercise in the form of walking 5 minutes 6 times in 14 days, physical exercise was done 1 hour after breakfast in the intervention group at the halfway house, two days after the child finished chemotherapy. Before the child's physical exercise is measured, fatigue scale using a multidimensional fatigue scale questionnaire, which contains 25 questions, all items have a value based on the Likert scale 0-4, and the assessment results will be changed in liner 0-100.

Furthermore, measurements of fatigue scales will be done again on the tenth day after physical exercise is given. Researchers conducted vital signs before and after physical exercise (heart rate, temperature, respiratory rate). The control group did not do physical exercise but vital sign examinations (heart rate, temperature, respiratory rate). Intervention is stopped if the child is unable to complete physical exercise. The child is treated or treated.

\section{RESULTS AND DISCUSSION}

In this section will be explained the results of research such as the distribution of subject frequency based on gender, age of the child and physical complaints that children often feel, will further explain the difference in the value of fatigue scale and the effect of giving physical exercise walking on the fatigue scale at RSUP Dr. M. Djamil Padang. The fatigue scale before the intervention measured on the first day, two days post-chemotherapy, will then be compared to the fatigue scale after physical exercise on the tenth day of the intervention. The following is outlined the interpretation of the results of the study of all variables.

Table 1. Distribution of Subjects By Gender In Intervention and Control Groups at RSUP Dr. M. Djamil Padang

\begin{tabular}{lcc}
\hline Characteristics & $\begin{array}{c}\text { Intervention Group } \\
(\mathbf{N = 1 1 )}\end{array}$ & $\begin{array}{c}\text { Control Group } \\
(\mathbf{N = 1 1 )}\end{array}$ \\
\hline Gender & & \\
Male & $4(36,4 \%)$ & $9(81,8 \%)$ \\
Female & $7(63,6 \%)$ & $2(18,2 \%)$ \\
\hline
\end{tabular}


Table 1 found that the 22 subjects of the highest gender consist of 13 males and nine females. The subjects of this study were, on average, diagnosed starting in 2018 to 2019. Acute lymphoblastic leukemia (ALL) can happen to males and females. The results of this study are supported by a survey in the United States in 2017 (World Health Organization, 2018), which said that males have more cancer than females and occur mostly at the age of $<16$ years. Still not known exactly the cause of ALL, many experts say in children, the incidence of leukemia is often associated due to mutations in somatic DNA. According to Apriany (2016), DNA mutation is caused by the activation of oncogenes or the deactivation of suppressive tumor genes and disruption of the regulation of cell death programs (apoptosis). Such mutations can occur spontaneously or due to the influence of radiation or exposure to carcinogens and are closely related to genetic factors in the sex of the child. In some people with leukemia, the incidence of leukemia increases in families. These genetic factors further influence the body to perform somatic DNA mutations closely related to the onset. Although no family history of illness was found in this study from the questionnaire results, the incidence of ALL may be caused by other factors such as viruses and environmental factors.

According to Mendri and Prayogi (2016), factors in the home environment close to radiation sources such as short circuits or exposure to radiation such as ultraviolet radiation make children have a 4.73 times higher risk of developing leukemia compared to children who do not have radiation exposure. In this study, 6 out of 13 males lived near a rubber factory, and 3 out of 9 females lived near a plantation area or rice field. Thus, according to the researchers' assumptions, radiation exposure due to environmental factors may increase the risk of developing sex-related ALL in children. According to Caru et al. (2019), gender is 4.243 times more at risk of developing cancer and dying from cancer than women. The gender of the child can affect several diseases and has a relationship with cancer-related fatigue, which has an impact, relapse or disruption of daily functions and activities in children undergoing chemotherapy. 
Table 2. Average Fatigue Score In ALL Children at RSUP Dr. M. Djamil Padang

\begin{tabular}{llccc}
\hline Variable & Group & Mean & SD & Min-Max \\
\hline & Intervention & & & \\
& $-\quad$ Pre Test & 31,18 & 3,842 & $26-38$ \\
Measurement & - Post Test & 47,64 & 2,292 & $45-52$ \\
\cline { 2 - 4 } scale (Fatigue) & Control & & & \\
& $-\quad$ Pre Test & 27,27 & 4,407 & $22-36$ \\
& - Post Test & 39,18 & 3,371 & $34-47$ \\
\hline
\end{tabular}

The study results were obtained in the intervention, and the control group experienced fatigue levels before the intervention. In the intervention group, there was a score of the lowest 26 and the highest 38 , and in the control group, there was a score of 22 and the highest 36 . Based on the interval of values 0-100 from the fatigue questionnaire scores, the score values in both groups fall into the category of often experiencing fatigue and enter the score interval (25-49). While after being given physical exercise, the intervention group score obtained the lowest score of 45 and highest 52 and in the control group the lowest score of 34 and the highest 47 who fall into the category of frequent interval fatigue (25-49) to sometimes fatigue interval values (50-74). Although there were subjects in the same category after the intervention, the score increase of each subject became the success of giving physical exercise of walking given.

Based on the results of the data analysis can be seen that before physical exercise in the intervention group, the average value was
31.18 (SD 3.842) and increased after physical exercise averaged 47.64 (SD 2.292). While in the control group obtained a fatigue scale (fatigue) before physical exercise, averaged 27.27 (SD 4.407) and increased without physical exercise with an average value of 39.18 (SD 3.371). It shows a difference in average value between the two groups before and after physical walking training against the fatigue scale in children with ALL at RSUP Dr. M. Djamil Padang.

According to NCCN (2017), fatigue related to cancer treatment is a side effect often felt by children who receive chemotherapy. It occurs due to a decrease in the number of red blood cells, which causes a decrease in the body's oxygen supply, nutrients and energy so that sufferers feel tired. Physiologically, fatigue can affect storage and increased use of energy reserves due to disease. Then obtained laboratory values of hemoglobin children are in the range of 6.49 - $15 \mathrm{gr} / \mathrm{dl}$, the number of leukocytes 5.2$10 / \mathrm{mm}^{3}$ and platelets $201-477 / \mathrm{mm}^{3}$. Three 
children with hemoglobin levels $<10 \mathrm{gr} / \mathrm{dl}$ have been dropped out of the study. It can also cause anemia and result in reduced delivery of oxygen into the blood, which causes tissue hypoxia to occur, changes in organ function so that children can experience fatigue or fatigue. This condition is an unavoidable part of the long chemotherapy process. According to Hermalinda and Novrianda (2016), children generally experience fatigue with an average scale of 43,55 in children aged seven years. In children younger than seven years of age, fatigue or fatigue is assessed based on parental perception. The level of fatigue experienced by children is quite severe. Research conducted by Dahlia,
Karim and Damanik (2019), in children undergoing chemotherapy experienced moderate fatigue as many as 72 people (50\%) and followed by a weight level of 61 people (42.4\%) and only slightly experienced mild levels as many as 11 people $(7.6 \%)$. In a study by Sulistini and Putri (2019), there were significant fatigue scale differences between the beginning of the first week and the end of the week (fourth week). According to Darma, Setiawan and Widiana (2021), significantly fatigue that increase during chemotherapy. Fatigue conditions that continue to be felt by children can affect the child's activity process.

Table 3. Effect of Physical Exercise Walking on Fatigue Scale in Intervention Groups and Control Groups Undergoing Chemotherapy at RSUP Dr. M. Djamil Padang

\begin{tabular}{|c|c|c|c|c|c|}
\hline Variable & & Mean & SD & $\begin{array}{c}\text { Mean } \\
\text { different }\end{array}$ & $\begin{array}{c}P- \\
\text { Value }\end{array}$ \\
\hline $\begin{array}{l}\text { Measurement } \\
\text { scale (Fatigue) }\end{array}$ & $\begin{array}{l}\text { - Pre Test } \\
\text { - Post Test }\end{array}$ & -14.182 & 8.982 & 1.062 & 0.000 \\
\hline
\end{tabular}

In this study, the normality test was conducted with the Shapiro Wilk test with results in the intervention group of pre-test (p-value 0.747) and post-test (p-value $0.104)$ and in the control group pre-test values ( $p$-value 0.207 ) and post-test ( $p$ value 0.234), so statistically normal distributed data with values ( $p$-value $\geq 0.05$ ). Because the data is normal, researchers continued to conduct statistical tests with paired t-tests to see if there was no difference in average value or the effect of physical exercise. Then a paired test was conducted in the pretest-posttest intervention group to see the effect of physical exercise on fatigue, obtained an average value of -14.182 (SD 8.982) with a difference of 1.062 if changed into the category of fatigue scale entered at the interval of value (75-100) which never 
means fatigue. Furthermore, in the statistical analysis results, physical exercise was on the fatigue scale ( $p$-value 0.000 ) in the intervention group after being given physical exercise in walking at RSUP Dr. M. Djamil.

This research is supported by $\mathrm{Su}$ et al. (2018). In his study, getting physical exercise walking in cancer patients, in general, can improve the quality of life of cancer patients. Similarly done by Darma, Setiawan and Widiana (2021), physical exercise, walking exercise lowered the level of fatigue or fatigue in cancer patients greater when compared to the control group. Sulistini and Putri (2019) also added that physical exercise could reduce fatigue from the first week of intervention. According to Alibhai et al. (2015), Hooke and Linder (2019), Stössel et al. (2020), physical exercise in the form of muscle stretching exercises is beneficial for children with cancer with ALL who undergo chemotherapy. Physical exercise can improve several aspects such as quality of life, decrease fatigue, improve physical fitness, and increase muscle strength.

Shrestha et al. (2018) mention that physical exercise is a series of regular gestures to maintain a healthy life and improve quality of life. Walking physical exercise is also recommended by NCCN (2017) as physical therapy in children with cancer. World Health Organization (2018) added that physiological, physical exercise could increase cardiorespiratory changes and muscle strength. NCCN (2017) recommends the condition of children with cancer that is safe to do physical exercise that is not anemia or red blood cell deficiency assessed from laboratory results of at least hemoglobin $10 \mathrm{gr} / \mathrm{dl}$, does not have thrombocytopenia, uric acid levels are not high or abnormal lymphadenopathy, do not experience mental retardation, have undergone chemotherapy stages of at least six months. The child's nutrition is in good condition.

In this study, after the child was taken measurements of the fatigue scale (pre-test), the child will be scheduled to be given intervention at the next meeting. Eleven children from the intervention group get physical exercise walking with 5 minutes done six times in 14 days, and 11 children control group is not given physical exercise. In this study, six people were found to drop out. As for the explanation, namely in the intervention group of 3 children droup out because of abnormal laboratory values, children should be referred to RSUP Dr. M. Djamil at the first exercise began. Abnormal laboratory values are laboratory results for control schedules in children who have undergone chemotherapy and are following. 
In this condition, the child can still do activities and should be referred for leukocyte enhancement therapy, child leukocyte value $\left(5,2-6,3 / \mathrm{mm}^{3}\right)$.

Furthermore, two children returned home in the control group and could not be contacted again on the 3rd observation. Then one child died on the fourth observation. The child suddenly asphyxiated and was referred to RSUP Dr. M. Djamil. The child died one day after being given intensive care. Chemotherapy works by stopping the growth of cancer cells that nest in the body. Although this treatment can help overcome cancer, chemotherapy also has many side effects.

According to Mendri and Prayogi (2016), acute leukemia definitive therapy involves cytotoxic chemotherapy using multiple drug combinations. Chemotherapy treatment that is undertaken requires a long, continuous and regular process in children. The treatment carried out results in physical problems, namely nausea, vomiting, sores in the oral cavity, hair loss, and peripheral nerve disorders such as numbness and tingling in the fingers and toes, or the heaviest is shortness of breath due to lack of.

In the control group, the average score also increased from the scores some children experienced changes. However, after categorizing the score, the child remained at the interval of grades (50-74), sometimes fatigued. This showed that changes in fatigue scores in the control group could be controlled by the general condition of the child at that time, where the child had a long rest period before the child got the following chemotherapy schedule. In the maintenance phase, the scheduled chemotherapy schedule is five weeks in contrast to the induction phase and consolidation phase scheduled once every 1-2 weeks in children with ALL. Based on the many hypotheses about the provision of physical exercise. In this study, there were changes in vital signs in the subject. Measurements were done in the intervention and control group 6 times, and measures were taken 10 minutes before physical exercise and 10 minutes after physical exercise in the group.

In this study, there were changes in the patient's vital signs before physical exercise walking heart rate with an average of 84.4, the average breathing is 21.7 , and the average body temperature of $35.8{ }^{\circ} \mathrm{C}$ is within the normal limit. Furthermore, measurements were taken after physical exercise with an average heart rate of 90.1, then the average breathing was 24.2, and the average body temperature was $35.9^{\circ} \mathrm{C}$. It is because the vital signs are within normal limits. So researchers assume that the 
administration of physical exercise does not affect the vital signs of some children. In measuring vital signs, two children had a change in temperature below $36.0^{\circ} \mathrm{C}$ to $35.1-35.7^{\circ} \mathrm{C}$, after physical exercise. It can be due to the general condition of children who experience increased energy needs.

Physical exercise given to children with ALL will certainly affect changes in the child's vital signs. According to the Komite Penanggulangan Kanker Nasional (2019), physical activity or physical exercise causes increased lactic acid levels in the muscles and blood and the temperature of the outdoor environment when doing physical activity and can increase body temperature. In measuring vital signs, two children had a change in temperature below $36.0^{\circ} \mathrm{C}$ to 35.1-35. $7^{\circ} \mathrm{C}$, after physical exercise. It can be due to the general condition of children who experience increased energy needs. Physical exercise given to children with ALL will certainly affect changes in the child's vital signs. Physical activity or physical exercise causes increased levels of lactic acid in the muscles and blood, in addition to the temperature of the outdoor environment when doing physical activity and can increase body temperature.

The temperature of the skin is different from the core temperature. The ambient temperature greatly influences the increase and decrease. Under normal circumstances, the human body can regulate the temperature in hot and cold environments through temperature-protective reflexes regulated by the hypothalamus (Putri, 2018). According to Mendri and Prayogi (2016), the decrease in temperature occurs due to the body's mechanism of temperature delivery difficulties to cope with cold temperature pressure where the core temperature is below the normal limit, the normal temperature of the human body is between $\quad 36.0-37.5^{\circ} \mathrm{C}$. Normal body temperature in children aged $>5$ years is $36.0^{\circ} \mathrm{C}$. Some experts say, to support physical exercise intervention in children with cancer in increasing energy needed balanced nutrition. It is done to avoid a decrease in the condition of children.

This study optimized nursing care by applying Levine conservation nursing theories and models using four conservation principles. The first principle of energy conservation carried out by researchers by maintaining children's activities is to provide physical exercise 5 minutes six times in 14 days. It is to improve the quality of life of children but does not make children lose a lot of energy. Second, the principle of structural integrity is carried out by researchers by providing a nutritional diet with high protein and calories according to the needs of children. Besides 
that, they advise parents to pay attention to what children consume during treatment and include the High-calorie high protein diet recommended by nutritionists from RSUP Dr. M. Djamil Padang.

Furthermore, the third principle is that personal integrity carried out by researchers is to keep the patient and family secret by not telling the identity or condition of the patient to others, respecting the rights of patients such as asking in advance what patients want and do not want to do at that time, creating a safe and comfortable environment by keeping objects that can harm patients, and providing social support and knowledge for patients and families. The fourth principle is a social principle where the researcher plays a professional role in helping the needs of patients and families. In this case, the researcher provides support and motive so that patients and families can still accept their condition with sincere and always trust. In children, researchers practice always pray and be more enthusiastic in practicing treatment every week. The four conservation principles researchers applied to the nursing process began with physical examination, walking, physical exercise intervention and evaluation in children with ALL.
This approach is expected to help children adapt to healing to the maximum in overcoming fatigue or fatigue due to the side effects of treatment. Physical exercise can be used as a choice of physical intervention that can be given to cancer patients. Physiologically physical exercise can improve general conditions and increase muscle strength (Shrestha et al., 2018). Doing physical exercise such as walking regularly can provide benefits for physical health. Doing can increase flexibility, increase endurance and muscle strength and improve heart fitness to improve the quality of life (World Health Organization, 2018). Life expectancy can be improved by doing minimal physical exercise such as walking to manage fatigue during treatment.

\section{CONCLUSION}

Based on the results of the study, the conclusion there was a difference in the average value of fatigue scale in the intervention group and control group before and after being given physical exercise in walking. So physical exercise can reduce fatigue in children with leukemia who undergo chemotherapy.

\section{ACKNOWLEDGEMENT}

Thanks to Dr. dr. Mayetti, Sp.A (K), Program Pasca Sarjana Magister Keperawatan Universitas Andalas Padang, 
Director, Ethical comitee, Diklat RSUP Dr.

M. Djamil Padang, Rumah Singgah Pasien

IZI West Sumatra, Rumah Singgah Pasien

Cahaya.

\section{REFERENCES}

Alibhai, S. M. H. et al. (2015) 'A phase II exercise randomized controlled trial for patients with acute myeloid leukemia undergoing induction chemotherapy', Leukemia research, 39(11), pp. 1178$1186 . \quad$ doi: https://doi.org/10.1016/j.leukres.2015.0 8.012 .

Apriany, D. (2016) Asuhan Keperawatan Anak Dengan Keganasan. 1st edn. Edited by N. F. Atif. Bandung: PT Refika Aditama.

Caru, M. et al. (2019) 'Childhood acute lymphoblastic leukemia survivors have a substantially lower cardiorespiratory fitness level than healthy Canadians despite a clinically equivalent level of physical activity', Journal of adolescent and young adult oncology, 8(6), pp. 674-683. doi: https://doi.org/10.1089/jayao.2019.002 4.

Dahlia, D., Karim, D. and Damanik, S. R. H. (2019) 'Gambaran Fatigue Pada Pasien Kanker Post Kemoterapi', Jurnal Ners Indonesia, 10(1), pp. 80-93. doi: http://dx.doi.org/10.31258/jni.10.1.8093.

Darma, G. S. P., Setiawan, I. G. B. and Widiana, I. G. R. (2021) 'Pengaruh Aktivitas Fisik Walking Exercise Program (WEP) terhadap Cancer Related Fatigue (CRF) pada Pasien Kanker Payudara di RSUP Sanglah', Jurnal Bedah Nasional, 5(1), pp. 9-15. doi:

https://doi.org/10.24843/JBN.2021.v05. i01.p02.
Goric, L. (2008) A Review of Pediatric Physical Therapy. Edited by J. Tecklin. USA: Taylor \& Francis. doi: https://doi.org/10.1080/0194263080230 9651.

Hermalinda, H. and Novrianda, D. (2016) 'Skor Fatigue pada Anak dengan Kanker di Ruang Perawatan Anak RSUP dr. M. Djamil Padang', Jurnal Keperawatan Sriwijaya, 3(1), pp. 4047.

Hooke, M. C. and Linder, L. A. (2019) 'Symptoms in children receiving treatment for cancer-part I: fatigue, sleep disturbance, and nausea/vomiting', Journal of Pediatric Oncology Nursing, 36(4), pp. 244-261. doi:

https://doi.org/10.1177/1043454219849 576.

Jitowiyono, S. (2018) Asuhan Keperawatan Pada Pasien Dengan Gangguan Sistem Hematologi. Manado: Pustaka Baru Press.

Kemenkes RI (2019) Profil Kesehatan Indonesia 2018. Jakarta: Kementerian Kesehatan RI. Available at: https://pusdatin.kemkes.go.id/resources /download/pusdatin/profil-kesehatanindonesia/PROFIL_KESEHATAN_20 18_1.pdf.

Komite Penanggulangan Kanker Nasional (2019) Pedoman Strategi \& Langkah Aksi Peningkatan Aktivitas Fisik. Jakarta: KPKN.

Mendri, N. K. and Prayogi, A. S. (2016) Asuhan Keperawatan pada Anak Sakit Bayi Resiko Tinggi. Yogyakarta: Pustaka Baru.

NCCN (2017) NCCN clinical practice guidelines in oncology. Available at: https://www.nccn.org/guidelines/guidel ines-detail ? category $=1 \& \mathrm{id}=1410$. 
Putri, K. W. (2018) Studi Epidemiologi Profil Klinis dan Laboratorium Pasien Leukemia Limfoblastik Akut Anak di RSUD $d r$ Soetomo. Universitas Airlangga.

Rekam Medis RSUP dr. M.Djamil (2020) Pengelolaan Data Leukemia. Padang.

Shrestha, A. D. et al. (2018) 'Cervical cancer prevalence, incidence and mortality in low and middle income countries: a systematic review', Asian Pac J Cancer Prev, 19(2), pp. 319-324. doi:

https://doi.org/10.22034/APJCP.2018.1 9.2.319.

Stössel, S. et al. (2020) 'Benefits of exercise training for children and adolescents undergoing cancer treatment: results from the randomized controlled MUCKI trial', Frontiers in Pediatrics, 8, p. 243. doi: https://doi.org/10.3389/fped.2020.0024
3.

Su, H. L. et al. (2018) 'Assessment of the effects of walking as an exercise intervention for children and adolescents with cancer: A feasibility study', European Journal of Oncology Nursing, 37, pp. 29-34. doi: https://doi.org/10.1016/j.ejon.2018.10.0 06.

Sulistini, R. and Putri, P. (2019) 'Latihan dengan Posisi Duduk Menurunkan Keletihan Penderita Diabetes Mellitus', in Proceeding Seminar Nasional Keperawatan, pp. 6-9.

World Health Organization (2018) Global action plan on physical activity 20182030: more active people for a healthier world. Geneva: World Health Organization. 